\title{
The importance of eating habits and physical activities among school students
}

\begin{abstract}
Healthy eating habit is one of the factors contributing to an improvement in one's health. Physical activities also help improve and maintain one's health. In this regard, this article discusses the importance of eating habits and physical activities among school students. In addition, health issues related to eating habits and the practice of physical activities are also highlighted. In overall, the results revealed that healthy eating habits and regular physical activities help one to maintain good health.
\end{abstract}

Keywords: eating habits, physical activity practices, school students, health problems
Volume 4 Issue 5 - 2019

\author{
Syed Kamaruzaman Syed Ali,' Misbon Onn \\ Hassan,' Zulakbal Abd Karim² \\ 'Department of Mathematics and Science Education, Faculty of \\ Education, University of Malaya, Malaysia \\ ${ }^{2}$ Faculty of Sports Science and Coaching, Sultan Idris Education \\ University, Malaysia
}

Correspondence: Syed Kamaruzaman Syed Ali, Department of Mathematics and Science Education, Faculty of Education, University of Malaya, Malaysia, Tel +60 I I 26340568 ,

Email syedkamaruzaman@gmail.com

\section{Introduction}

Eating habits and physical activities are two topics found in the syllabus of Physical Education and Health in secondary schools. ${ }^{1}$ The aspects of eating habits exposed to school students include healthy and safe eating habits, unhealthy eating habits and the effects of eating habits. ${ }^{1}$ As for physical activities, secondary school students are taught about health-related fitness, physical fitness, and sports and

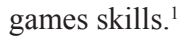

The importance of eating habits and physical activities has always been emphasized in the teaching and learning sessions of Physical Education and Health Education. ${ }^{2}$ This is because both aspects are the key pillars to Secondary School Integrated Curriculum of Physical Education and Health Education, which is drafted based on the National Education Philosophy in producing a balanced generation in terms of physical, emotional, spiritual, intellectual and social. ${ }^{2}$ This places secondary school teenagers as an important asset of the nation as future leaders. Good eating habitd and active involvement in physical activities among teenagers or secondary school students in Malaysia should always be emphasized by every party. ${ }^{2}$

According to World Health Organization, ${ }^{3}$ teenager is defined as a group of people between the ages of 10 and 19. The sub-categories of teenagers in Malaysia range from early teens (10-14 years), mid teens (15-17 years) and late teens (18-19 years). Ironically, Malaysia has a large population of teenagers ( 9.4 million or 29.4 percent of the total 32.4 million population) and the majority of them are school students (Department of Statistics Malaysia, 2018) and among them, 2.076 million are secondary school students (Ministry of Education, 2019).

\section{Eating habits and health problems}

The socio-economic developments in the country over the last decade have influenced the lifestyle of Malaysians, especially in terms of eating habits. This affects the nutritional status and body mass index (BMI) status of all ages, including high, medium and low socio-economic groups, including secondary school students. ${ }^{4}$ The reduction of physical activities and unhealthy lifestyles are also a major contributing factor to overweight and obesity among students comprising children, teenager and adults. ${ }^{5-7}$ However, the issue of malnutrition and weight loss is still occuring in Malaysia. The issue of obesity and weight loss among tennagers are closely related to eating habits. ${ }^{8}$

Changes in eating habits and inactive lifestyles are known to be associated with changes in health status and contribute to increased risk of chronic diseases such as type 2 diabetes, cardiovascular diseases, hypertension and certain cancers. ${ }^{9}$ It has also drastically reduces the quality of life as well as increase psychosocial problems such as depression, lack of self-confidence, job discrimination and other forms of social stigmatization. ${ }^{9}$

The term eating habits is often used to describe the individual 'eating patterns', either children, teenager or adults in every meal, such as main meals (for example breakfast, lunch or dinner) or small meals (for example, supper or snack). ${ }^{10}$ Lately, the trend has shown that most harmful diseases occur as a result of unhealthy lifestyle practices. Malaysians have been exposed to unhealthy lifestyles since childhood..$^{10}$ Many younger generation today, especially school students do not care about the importance of having breakfast. They ignore breakfast for various reaSsons such as lack of appetite in the morning and not being able to prepare breakfast. ${ }^{10}$

According to Mohamad, ${ }^{11}$ intellectual development is also influenced by good eating habits. Students who have low blood pressure due to poor eating habits will become inactive, constantly tired and drowsy and cause them to focus less on their studies. Therefore, good nutrition is of utmost importance in generating proper mental growth among students. Unhealthy eating habits and physical inactivities among school children could pose a threat to their intellectual development as their brain could not function well. 


\section{Physical activities and health problems}

The current trend in this era of cyber is teenagers, especially secondary school students spend more time on the internet. This has led them to become addicted to online games and social networks to the point that they find it difficult to adapt to real-world communication. These groups are also found to be lacking in doing outdoor and physical activities. This situation will expose the teenagers, especially secondary school students to psychological and health problems. ${ }^{12}$

Physical inactivity is a public health problem today and is the fourth leading cause of death worldwide. ${ }^{13}$ It is an important contributor to major non-infectious diseases. ${ }^{14,15}$ Adequate physical activities has great health benefits for children and teenagers especially school children in terms of improving cardiovascular health, mental health and academic performance. ${ }^{16-18}$ Although there are numerous conclusive benefits, most teenagers, especially school students fail to meet the recommended physical activity guidelines. This in turn increases the risk of obesity.

Obesity is a complex issue and the cause of many chronic health problems worldwide. In Malaysia, obesity, once considered a phenomenon in the city, has now spread to the rural population at an alarming rate. As Malaysia continues to grow towards a country of advanced economic status, it is expected that its health of people will continue to decline. ${ }^{19}$ The latest WHO report puts Malaysia first in Southeast Asia and sixth in Asia in terms of obesity. The WHO report (2014) revealed that in less than a decade, the obesity rate has increased dramatically worldwide including Malaysia.

\section{Closure}

Through physical activities, i.e. doing activities to enhance fitness and health in a fun environment while also applying the skills of managing healthy lifestyle practices through healthy and proper eating habit, addressing the issues of eating habits, physical inactivity, obesity and weight loss among teenagers, especially secondary school students is expected to be a national priority for secondary school students in achieving the objectives of the Secondary School Curriculum Standard (KSSM) in Physical Education and Health Education (PEHE).

\section{Acknowledgement}

None.

\section{Conflicts of interest}

The authors declare that there is no conflict of interest.

\section{References}

1. KPM-kementerian pendidikan malaysia. KSSM pendidikan jasmani dan pendidikan kesihatan.dokumen standard kurikulum dan pentaksiran. bahagian pembangunan kurikulum, kementerian pendidikan Malaysia. Kuala Lumpur. 2015.

2. KPM-Kementerian Pendidikan Malaysia. KSSM pendidikan jasmani dan pendidikan kesihatan dskp tingkatan 4 dan 5. bahagian pembangunan kurikulum, kementerian pendidikan malaysia, Kuala Lumpur. 2018.

3. http://apps.who.int/adolescent/seconddecade/section $2 /$ page $1 /$ recognizingadolescen $\% 20 \mathrm{e} . \mathrm{html}$

4. Ismail MN, Norimah $\mathrm{AK}$, Poh BK, et al. Nutritional status and dietary habits of primary school children in peninsular Malaysia. UKM/Nestle Report. Department of Nutrition and Dieteteics,UKM, Kuala Lumpur; 2009.

5. Institute for public health. national health and morbidity survey 2006 (NHMS III): nutritional status. Ministry of Health. Malaysia; 2008.

6. Institute for public health. National health and morbidity survey 2014 malaysian adult nutrition survey: survey findingss (Volume II). Ministry of Health. Malaysia. 2014

7. Institute for public health. National health and morbidity survey 2015 : non-communicable diseases, risk factors \& other health problems (Volume II). Ministry of Health. Malaysia. 2015.

8. National coordinating committee on food and nutrition. National plan of action for nutrition of malaysia III, 2016-2025. Ministry of Health Malaysia. Kuala Lumpur. 2006.

9. World of health organization WHO. Health systems: improving performance. World health organisations, Geneva; 2000

10. Shariff ZM, Bukhari SS, Othman $\mathrm{N}$, et al. Nutrition education intervention improves nutrition knowledge, attitude and practices of primary school children: a pilot study. International Electronic Journal of Health Education. 2008;(11):119-132.

11. Mohamad N. Harian Metro. Ibubapa antara penyebab masalah berat badan berlebihan: Artikel. 2006.

12. Ministry of Health Malaysia. Review and analysis of nutrition studies in Malaysia. a report of studies conducted by malaysian universities. public health institute, Ministry of Health Malaysia, Kuala Lumpur. 2011.

13. Cora LC, Estelle VL, Shigeru I, et al. The pandemic of physical inactivity: global action for public health. The Lacent. 2012;380(9838):294-305.

14. Farid A, Mohamed RA, Ayesha AR, et al. The Prevelence of physical activity and sedentary lifestyle among adolescents in palestine. Can J Basic Appl Sci. 2013;03(01):135-144.

15. Shariff R, Chong KH, Zakaria NH, et al. Results From Malaysia's 2016 Report Card on Physical Activity for Children and Adolescents. J Phys Act Health. 2016;13(11): S201-S205.

16. Ekelund U, Luan J, Sherar LB, et al. A moderate to vigorous physical activity and sedentary time and cardiometabolic risk factors in children and adolescents. JAMA. 2012;307:704-712.

17. Biddle SJH, Asare M. Physical activity and mental health in children and adolescents: a review of review. Br J Sports Med. 2011;45:886-895.

18. Singh A, Uijtdewilligen L, Twisk JW, et al. Physical activity and performance at school: a systematic review of the literature including a methodological quality assessment. Arch Pediatr Adolesc Med. 2012;166:49-55.

19. Ismail $\mathrm{MN}$, Chee $\mathrm{SS}$, Nawawi $\mathrm{H}$, et al. Obesity in malaysia. the international association for the study of obesity. Obesity Review. 2002;3:203-208. 